\title{
KORELASI ANTARA KADAR TRIASILGLISEROL DENGAN KADAR GLUKOSA DARAH PENDERITA DIABETES MELLITUS
}

\author{
Ni Putu Eka Supriati \\ Universitas Pendidikan Ganesha \\ Singaraja, Indonesia \\ e-mail: supriati@gmail.com
}

\begin{abstract}
Abstrak
Penelitian ini adalah penelitian deskriptif yang bertujuan untuk: (1) mengetahui apakah terdapat korelasi antara kadar triasilgliserol dengan kadar glukosa darah penderita diabetes mellitus, (2) menentukan persentase kasus hipertriasilgliserolemia pada penderita diabetes mellitus di Rumah Sakit Sanglah Denpasar. Subjek penelitian ini adalah serum penderita diabetes mellitus, sedangkan objek penelitian ini adalah kadar triasilgliserol dan kadar glukosa darah penderita diabetes mellitus. Jumlah subjek penelitian adalah 17 serum dari 17 penderita diabetes mellitus. Penelitian dilakukan di Laboratorim Patologi Klinik Rumah Sakit Sanglah Denpasar, dari tanggal 14 Juni 2005 sampai dengan tanggal 25 Juni 2005. Kadar triasilgliserol dan kadar glukosa darah pada serum ditentukan dengan alat Beckman Coulter CX 7. Data kemudian dianalisis dengan analisis korelasi product momen dan analisis deskriftif. Hasil penelitian menunjukkan bahwa (1) terdapat korelasi positif antara kadar triasilgliserol dengan kadar glukosa darah penderita diabetes mellitus, dan (2) persentase terjadinya hipertriasilgliserolemia pada penderita diabetes mellitus adalah $100 \%$.
\end{abstract}

Kata kunci: Triasilgliserol, Glukosa Darah, dan Diabetes Mellitus

\section{Pendahuluan}

Diabetes mellitus merupakan salah satu penyakit berupa gangguan metabolisme, yang disebabkan oleh defesiensi sekresi insulin, resistensi insulin, atau gabungan kedua penyebab tersebut (Suastika, K. 1994: 47). Gangguan metabolisme yang terjadi dapat berupa gangguan metabolisme primer dan gangguan metabolisme sekunder. Gangguan metabolisme primer yang terjadi adalah gangguan metabolisme karbohidrat. Sedangkan salah satu gangguan metabolisme sekunder yang terjadi adalah gangguan metabolisme lipid, khususnya metabolisme triasilgliserol (Baron, D.N. 1998: 70).

Glukosa dalam tubuh dapat berasal dari makanan dan sintesis glukosa endogen. Glukosa yang berasal dari makanan pertama akan masuk ke dalam sel. Selanjutnya, glukosa mengalami fosforilasi oleh suatu heksokinase menjadi glukosa 6-fosfat. Glukosa 6-fosfat selanjutnya dapat masuk ke dalam jalur metabolik. Jalur metabolik tersebut adalah jalur glukolisis dan jalur pentosa fosfat. Sintesis glukosa endogen terjadi melalui proses glukoneonenesis. Kelebihan glukosa akan disimpan dalam bentuk glikogen (Marks, D.B. et. al. 1996: 381).

Pada penderita diabetes akan terjadi gangguan metabolisme glukosa akibat defesiensi sekresi insulin, resistensi, atau gabungan keduanya. Hal ini mengakibatkan terjadinya peningkatan sintesis glukosa endogen melalui proses glukoneogenesis, penurunan glikolisis, penurunan sintesis glikogen, dan peningkatan katabolisme glikogen (Baron, D.N. 1998: 68).

Triasilgliserol dalam tubuh dapat berasal dari makanan dan sintesis dalam tubuh. Triasilgliserol makanan dikemas dalam kilomikron. Triasilgliserol hasil sintesis dikemas dalam Very Low Density Lipoprotein. Kedua triasilgliserol ini akan diedarkan dalam tubuh. Pada keadaan energi sel rendah triasilgliserol akan dihidrolisi menjadi asam lemak, selanjutnya mengalami $\beta$ oksidasi menghasilkan energi. Kelebihan triasilgliserol akan disimpan dalam jaringan adipose.

Pada penderita diabetes mellitus terjadi gangguan metabolisme triasilgliserol karena adanya defesiensi sekresi insulin, resistensi, atau gabungan keduanya. Gangguan tersebut berupa peningkatan lipolisis jaringan adiposa dan penurunan katabolisme kilomikron serta Very Low Density Lipoprotein (VLDL) (Marks, D.B. et. al. 1996: 552). Gangguan metabolisme 
triasilgliserol ini mengakibatkan terjadinya hipertriasilgliserolemia, yaitu peningkatan kadar triasilgliserol dalam darah (Suastika, K. 1994: 70).

Untuk menganalisis kadar triasilgliserol dan kadar glukosa dalam darah dapat dilakukan dengan metode kolorimetri enzimatis. Pemeriksaan kadar triasilgliserol dalam darah dilakukan dengan menghidrolisis triasilgliserol menghasilkan gliserol. Gliserol selanjutnya difosfirilasi dan dioksidasi menghasilkan dihidroksi aseton fosfat dan $\mathrm{H}_{2} \mathrm{O}_{2}$. Hidrogen peroksida direaksikan dengan 4 aminofenazone 4 - klorofenol menghasilkan 4 - (P-benzoquinonin-mono-imino)fenazon yang berwarna merah. Pemeriksaan glukosa darah dilakukan dengan mengoksidasi glukosa menjadi quinonimina yang berwarna merah. Senyawa berwarna ini selanjutnya diukur dengan alat spektrofotometer.

Gangguan metabolisme karbohidrat mengakibatkan terjadinya hiperglikemi, yaitu peningkatan kadar glukosa darah dari kadar patologis normal. Hiperglikemi dapat terjadi karena adanya defesiensi sekresi insulin, resistensi, atau gabungan keduanya, akan mengakibatkan terjadinya peningkatan sintesis glukosa endogen melalui proses glukoneogenesis, penurunan glikolisis, penurunan sintesis glikogen, dan peningkatan katabolisme glikogen (Baron, D.N. 1998: 68).

Gangguan metabolisme triasilgliserol mengakibatkan terjadinya hipertriasilgliserolemia, yaitu peningkatan kadar triasilgliserol dalam darah dari kadar patologis normal (Suastika, K. 1994: 70). Hipertriasilgliserolemia terjadi karena adanya defesiensi sekresi insulin, resistensi, atau gabungan keduanya, akan mengakibatkan terjadinya peningkatan lipolisis jaringan adiposa dan penurunan katabolisme kilomikron serta Very Low Density Lipoprotein (VLDL) (Marks, D.B. et. al. 1996: 552).

Secara empirik, WHO Multinational Study mendapatkan bahwa prevalensi hipertriasilgliserolemia pada populasi dengan diabetes mellitus dua kali lebih tinggi daripada populasi tanpa diabetes mellitus di negara-negara barat. San Antonio Study, yaitu suatu survey populasi tentang diabetes dan penyakit jantung koroner, menemukan bahwa lebih dari $80 \%$ responden dengan diabetes menderita dislipidemia. Penelitian di Dresden juga menemukan bahwa prevalensi hipertriasilgliserolemia pada populasi dengan diabetes mellitus dua kali lebih tinggi daripada populasi tanpa diabetes mellitus. Di Indonesia prevalensi terjadinya dislipidemia yang berupa hipertriasilgliserolemia pun tinggi yaitu mencapai $40 \%$ dari penderita diabetes (Suyono, S. 1994: 80).

Dari uraian di depan, ternyata defesiensi sekresi insulin, resistensi insulin, atau gabungan keduanya yang terjadi pada penderita diabetes mellitus, selain dapat mempengaruhi metabolisme glukosa juga dapat mempengaruhi metabolisme triasilgliserol. Hal ini juga dapat dilihat dari bukti empiris beberapa orang peneliti yang memperoleh hasil adanya hipertriasilgliserolemia pada penderita diabetes mellitus. Dengan demikian dapat diduga terdapat korelasi yang tidak langsung antara kadar triasilgliserol dengan kadar glukosa darah penderita diabetes mellitus. Untuk itu perlu dilakukan penelitian tentang korelasi antara kadar triasilgliserol dengan kadar glukosa darah penderita diabetes mellitus. Selain itu penelitian ini penting dilakukan karena di Indonesia penelitian di bidang lipid pada penderita diabetes mellitus belum banyak dilakukan, kalaupun dilakukan hanya berupa penelitian untuk mencari prevalensi terjadinya dislipidemia yang bersifat hospital based (Suyono, S. 1994: 80). Penelitian mendetail, seperti triasilgliserol, LDL, HDL, VLDL, dan HDL belum banyak dilakukan. Penelitian ini juga akan mencari persentase terjadinya hipertriasilgliserol pada penderita diabetes mellitus untuk memperkaya hasil-hasil penelitian terdahulu.

\section{Metode}

Penelitian ini adalah penelitian deskriftif yang bertujuan untuk mengetahui apakah terdapat korelasi antara kadar triasilgliserol dengan kadar glukosa darah penderita diabetes mellitus dan untuk mengetahui persentase terjadinya hipertriasilgliserolemia pada penderita diabetes mellitus.

Penelitian dilakukan di Rumah Sakit Sanglah Denpasar dari tanggal 14 Juni 2005 sampai dengan tanggal 25 Juni 2005. Subjek penelitian ini adalah serum penderita diabetes mellitus dan objek penelitian adalah kadar triasilgliserol serta kadar glukosa darah.

Pengumpulan data dilakukan melalui dua tahap yaitu tahap persiapan dan tahap pengumpulan data. Pada tahap persiapan dilakukan persiapan instrumen dan bahan penelitian. Instrumen penelitian yang digunakan adalah Beckman Coulter CX7, sample cup, dan secto. Bahan yang digunakan adalah reagen triasilgliserol (dari Buffer $\mathrm{pH} \mathrm{6,8/4-klorofenol} \mathrm{/} \mathrm{enzim}$ (lipase, gliserol kinase, gliserol fosfatase oksidase), reagen glukosa (R1 buffer/ATP/NADH, R2 
heksokinase/glukosa 6-fosfat), serum kontrol untuk triasilgliserol dan glukosa, serta multikalibrator.

Pada tahap pengumpulan data dilakukan pengambilan darah dan preparasi darah menjadi serum, serta analisis serum. Pengambilan darah dan preparasi darah menjadi serum dilakukan dengan cara sebagai berikut.

1. Pasien dipuasakan 10-14 jam termasuk berhenti merokok dan olahraga

2. Pasien tidak mendapatkan obat yang mempengaruhi kadar lipid dalam dua minggu terakhir, Pasien dalam keadaan metabolik stabil, dan tidak stres karena penyakit akut.

3. Pasien dalam posisi duduk selama minimal 5 menit, kemudian lengan pasien diluruskan di atas bantal, selanjutnya dipasang torniquet kira-kira $10 \mathrm{~cm}$ di atas siku

4. Lokasi tusukan pada daerah vena cubitus dibersihkan dengan alkohol

5. Darah diambil dengan menggunakan vakutener.

6. Darah selanjutnya diubah menjadi serum dengan cara mensentrifugasi darah tersebut, sehingga diperoleh supernata (serum) dan endapan darah berupa sel-sel darah. Selanjutnya serum ditempatkan pada sample cup

Analisis serum untuk mengetahui kadar triasilgliserol dan kadar glukosa darah dilakukan dengan metode kolorimetri enzimatis menggunakan alat Beckman Coulter CX 7. Alat ini melakukan pemeriksaan secara autoanalyser. Sebelum dilakukan pemeriksaan sampel dilakukan kalibrasi dan control.

Data berupa kadar triasilgliserol dan kadar glukosa darah penderita diabetes mellitus. dianalisis menggunakan analisis dua teknik analis data. Analisi korelasi product moment diguakan untuk mengetahui apakah terdapat korelasi antara kadar triasilgliserol dengan kadar glukosa darah penderita diabetes mellitus, dan analisis deskriftif untuk mengetahui persentase terjadinya hipertriasilgliserolemia pada penderita diabetes mellitus.

Dalam Made Gunada (2005) disebutkan, jika penelitian menggunakan sampel, sebelum kesimpulan atas penolakan dan penerimaan hipotesis penelitian dilakukan, maka terlebih dahulu dilakukan uji keberartian nilai koefesien korelasi pada populasi. Namun, penelitian ini adalah penelitian deskriftif dan menggunakan subjek serta objek tanpa menggunakan sampel dan populasi, sehingga harga $r$ yang diperoleh tidak perlu diuji signifikansinya dalam populasi sebalum ditarik suatu kesimpulan. Jadi jika diperoleh harga $0<r \leq 1$ atau $-1 \leq r<0$, maka dapat disimpulkan terdapat hubungan antara variabel $X$ dan $Y$. Dengan kata lain hipotesis penelitian diterima. Keeratan hubungan diinterpretasikan dengan menggunakan aturan Guiford atau Guilford's Empirical Rule.

Untuk mengetahui besarnya persentase terjadinya hipertriasilgliserol pada penderita diabetes mellitus data dianalisis secara deskriftif yaitu dengan membandingkan kadar triasilgliserol pada serum yang diperoleh dengan kadar patologis triasilgliserol dalam plasma. Jumlah subjek yang mengalami hipertriasilgliserolemia dan jumlah subjek penelitian digunakan untuk mencari persentase pasien yang mengalami hipertriasilgliserolemia.

\section{Hasil dan Pembahasan}

Hasil Data kadar triasilgliserol dan kadar glukosa darah yang diperoleh ini selanjutnya dianalisis dengan menggunakan dua teknik analisis data. Untuk rumusan masalah pertama, yaitu untuk mencari apakah terdapat korelasi antara kadar triasilgliserol dengan kadar glukosa darah penderita diabetes mellitus digunakan analisis korelasi product moment dengan hasil sebagai berikut: (1) koefesien korelasi $(r)=0,6$ dan (2) koefesien determinasi $\left(r^{2}\right)=0,36$.

Untuk mencari persentase kejadian hipertriasilgliserolemia pada penderita diabetes mellitus data dianalisis secara deskriptif. Hasil analisis data memperoleh 17 orang penderita diabetes mellitus di Rumah Sakit Sanglah yang serumnya menjadi subjek penelitian ini, semuanya mengalami hipertriasilgliserolemia. Dengan menggunakan Persamaan 2, diperoleh persentase hipertriasilgliserolemia sebesar $100 \%$.

Dari hasil analisis data diperoleh harga koefisien korelasi sebesar 0,6. Nilai ini berada pada rentangan $0<r \leq+1$. Sesuai dengan aturan Guilford pada Tabel 3.1, terdapat koralasi antara kedua variabel penelitian ini. Dengan demikian hipotesis penelitian $\mathrm{H}_{\mathrm{i}}$ diterima. Harga $r$

yang diperoleh ini berada pada rentangan $\geq 0,4 \longrightarrow<0,7$; sehingga berdasarkan aturan Guilford pada Tabel 3.1 tergolong korelasi sedang; hubungan kuat. Hal ini menandakan ada hubungan yang kuat antara kadar triasilgliserol dengan kadar glukosa darah penderita diabetes mellitus. 
Harga koefisien korelasi $(r)$ yang diperoleh adalah positif, dengan kata lain terdapat korelasi yang positif antara peningkatan kadar triasilgliserol dengan peningkatan kadar glukosa darah. Jika kadar glukosa darah penderita diabetes mellitus meningkat maka kadar triasilgliserol akan meningkat juga.

Hasil yang diperoleh ini sejalan dengan teori-teori yang terdapat pada kajian pustaka. Korelasi yang terjadi adalah korelasi tidak langsung karena kadar triasilgliserol tidak secara langsung mempengaruhi kadar glukosa darah. Korelasi yang terjadi disebabkan karena defesiensi sekresi insulin, resistensi insulin, atau gabungan keduanya yang terjadi pada penderita diabetes mellitus, mempengaruhi metabolisme glukosa darah dan triasilgliserol.

Adanya defesiensi sekresi insulin, resistensi, atau gabungan keduanya pada penderita diabetes mellitus mengakibatkan terjadinya gangguan metabolisme primer, yaitu metabolisme glukosa dan gangguan metabolisme sekunder, yaitu triasilgliserol. Gangguan metabolisme glukosa yang terjadi adalah peningkatan sintesis glukosa endogen melalui jalur glikoneogenesis, penurunan penggunaan glukosa, peningkatan penguraian glikogen, dan penurunan pembentukan glikogen. Peningkatan glikolisis terjadi karena dengan adanya defesiensi sekresi insulin, resistensi insulin, atau gabungan keduanya mengakibatkan peningkatan pengeluaran prekursol glikolisis yaitu gliserol. Penurunan glikolisis terjadi karena terjadi penurunan aktifasi enzim fruktosa 2,6-bisfosfat, suatu enzim utama dalam glikolisis. Peningkatan penguraian glikogen dan penurunan sintesisnya terjadi karena defesiensi sekresi insulin, resistensi insulin atau gabungan keduanya mengakibatkan terjadinya peningkatan fosforilasi glikogen fosforilase menjadi bentuk enzim aktif. Akibatnya terjadi penguraian glikogen dan penghambatan sintesis glikogen (Mark, D.B. et. al. 1996: 417-418).

Gangguan metabolisme triasilgliserol terjadi karena defesiensi sekresi insulin, resistensi, atau gabungan keduanya tersebut juga mengakibatkan terjadinya peningkatan lipolisis dan penurunan katabolisme VLDL dan kilomikron. Hal ini dapat terjadi karena defesiensi insulin akan menghambat kerja lipoprotein lipase (LPL), sehingga katabolisme Very Low Density Lopoprotein (VLDL) dan kilomikron berkurang. Hambatan katabolisme ini terjadi karena dengan defesiensi insulin mengakibatkan terjadinya penurunan kadar insulin, dengan demikian terjadi penurunan sintesis dan sekresi lipoprotein lipase, suatu enzim katabolik VLDL dan kilomikron. Penurunan sekresi lipoprotein lipase mengakibatkan terjadinya penurunan katabolisme VLDL dan kilomikron. Defisiensi insulin juga mengakibatkan rasio glukagon/insulin meningkat, sehingga terjadi peningkatan kadar adenisin monofosfat siklis (cAMP). Peningkatan kadar CAMP akan meningkatkan aktifasi protein kinase A, selanjutnya peningkatan ini akan mengakibatkan peningkatan fosforilasi hormone sensitive lipase, yaitu suatu hormon katabolik jaringan adiposa. Peningkatan fosforilasi hormone sensitive lipase akan mengakibatkan terjadinya lipolisis jaringan adiposa, yaitu terjadi hidrolisis triasilgliserol jaringan adiposa menjadi asam lemak bebas dan gliserol. Hati akan menggunakan asam lemak bebas ini untuk sintesis triasilgliserol. Triasilgliserol hasil sintesis hati ini tidak disimpan dalam hati tetapi disekresikan keluar hati dalam bentuk VLDL. Adanya resistensi insulin mengakibatkan terjadinya resistensi jaringan adiposa terhadap penghambatan insulin pada hormone sensitive lipase dan perangsangan insulin pada lipoprotein lipase. Dengan demikian akan terjadi peningkatan lipolisis dan penurunan katabolisme VLDL dan kilomikron. Hal tersebut akan mengakibatkan peningkatan konsentrasi VLDL dan kilomikron dalam darah, yang secara klinis ditandai dengan peningkatan kadar triasilgliserol. Hal inilah yang menyebabkan terdapat korelasi positif antara kadar triasilgliserol dengan kadar glukosa darah penderita diabetes mellitus.

Harga koefisien determinasi $\left(r^{2}\right)$ yang diperoleh dalam penelitian ini adalah 0,36; yang berarti hanya $36 \%$ kadar triasilgliserol berhubungan dengan kadar glukosa darah penderita diabetes mellitus. Dengan demikian hanya $36 \%$ peningkatan kadar triasilgliserol pada subjek penelitian disebabkan oleh defesiensi sekresi insulin, resistensi insulin, atau gabungan keduanya yang terjadi pada penderita diabetes mellitus, sedangkan $64 \%$ oleh faktor-faktor lain. Faktor-faktor tersebut antara lain hipertriasilgliserol primer, hipertensi, gagal ginjal kronis, pemakaian obat-obat tertentu, infark miakard, penyakit hati, atau kehamilan (Konsensus Nasional Pengelolaan Dislipidemia Indonesia olah Forum Studi Arteroskerosis dan Penyakit Vaskuler Indonesia. 1994: 7).

Hasil analisis data menunjukkan bahwa persentase kejadian hipertriasilgliserol pada penderita diabetes mellitus di Rumah Sakit Sanglah Denpasar adalah $100 \%$, yang berarti semua penderita diabetes mellitus yang serumnya menjadi subjek penelitian ini mengalami hipertriasilgliserolemia. Hal ini sesuai dengan teori yang menyatakan bahwa, Jika terjadi defesiensi sekresi insulin, resistensi insulin, atau gabungan keduanya, maka akan mengakibatkan gangguan metabolisme glukosa dan lipid dalam hal ini adalah triasilgliserol. 
Gangguan metabolisme triasilgliserol yang terjadi adalah peningkatan kadar triasilgliserol. Sehingga seorang penderita diabetes akan menderita hipertriasilgliserolemia.

Hasil penelitian ini menunjukkan bahwa kemungkinan seorang penderita diabetes mellitus menderita hipertriasilgliserolemia adalah $100 \%$, dengan kata lain seorang penderita diabetes mellitus pasti menderita hipertriasilgliserol.

Jika dibandingkan dengan hasil-hasil penelitian lain yang sejenis, maka hasil yang diperoleh ini lebih tinggi. Hasil penelitian dengan prevalensi tertinggi adalah San Antony Study, suatu survey tentang diabetes dan hipertriasilgliserolemia diperoleh angka 80\% (Slamet, Suyono. 1994). Tingginya persentase yang diperoleh kemungkinan disebabkan karena penderita diabetes melitus yang serumnya menjadi subjek penelitian ini telah mengalami penyakit diabetes mellitus dalam jangka waktu yang panjang, sehingga gejala ini merupakan komplikasi jangka panjang diabetes mellitus (Slamet Suyono, 1994). Kemungkinan lain adalah penderita diabetes mellitus yang serumnya menjadi subjek penelitian ini kurang mendapat pengobatan, sehingga kadar insulinnya tidak terkontrol.

\section{Simpulan dan Saran}

Berdasarkan hasil dan pembahasan di depan, dapat disimpulkan hal-hal sebagai berikut: (1) terdapat korelasi positif antara kadar triasilgliserol dengan kadar glukosa darah pada penderita diabetes mellitus dan (2) persentase hipertriasilgliserolemia pada penderita diabetes mellitus di Rumah Sakit Sanglah Denpasar dari tanggal 14 Juni 2005 sampai dengan 25 Juni 2005 adalah $100 \%$.

Ada beberapa hal yang dapat disarankan terkait dengan hasil penelitian ini yaitu: (1) sebaiknya dilakukan pemeriksaan rutin kadar triasilgliserol penderita diabetes mellitus agar dapat dicegah terjadinya resiko penyakit kardiovaskuler, (2) dilakukan penyuluhan tentang bahaya diabetes mellitus kepada masyarakat, dan (3) dilakukan penelitian serupa dengan metode sampling yang lebih baik sehingga hasil yang diperoleh dapat digeneralisasi.

\section{Daftar Pustaka}

Baron, D.N. 1998. Kapita Selekta Patologi Klinik Edisi 4. Terjemahan Petrus, A. dan Johannes, G. A Short Textbook of Chemical Patologi. 1997. Jakarta: EGC

Gunada, M. 2005. Hubungan Antara Penempatan dan Pelayanan Terhadap Kepuasan Kerja Guru SDN di Lingkungan Dinas Kebudayaan dan Pariwisata Kabupaten Jembrana (tidak diterbitkan). Program Pascasarjana IKIP Negeri, Singaraja

Hardjono dkk. 2002. Interpretasi Hasil Tes Laboratorium Diagnostik. : Makasar: Lembaga Penerbit Universitas Hasanuddin

Marks, D.B. 1996. Biokimia Kedokteran Dasar Sebuah Pendekatan Klinis. Terjemahan Brahm, U.P. Basic Medical Biochemistry A Clinical Aprpoach. 1996. Jakarta: EGC

Suastika, K. 1994. "Endokrinologi". Dalam Komite Farmasi dan Terapi RS P Sanglah (Ed) Pedoman Diagnosa dan Terapi Penyakit Dalam. Denpasar: Fakultas Kedokteran UNUD

Suyono. 1994. "Dislipidemia Pada Diabetes Mellitus Diagnosis dan Penatalaksanaan". Dalam Siman, E. et. al (Ed). Warta HKKI. (hlm. 79-84). Jakarta: Bagian Patoligi Klinik FK UI 